\title{
Article
}

\section{Analysis of Free Sugars, Organic Acids, and Fatty Acids of Wood Apple (Limonia acidissima L.) Fruit Pulp}

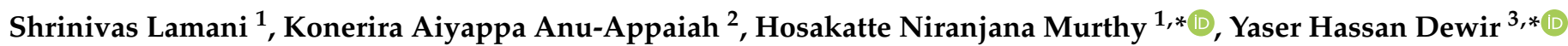 \\ and Jesamine J. Rikisahedew 4 (D)
}

check for

Citation: Lamani, S.; Anu-Appaiah, K.A.; Murthy, H.N.; Dewir, Y.H.; Rikisahedew, J.J. Analysis of Free Sugars, Organic Acids, and Fatty Acids of Wood Apple (Limonia acidissima L.) Fruit Pulp. Horticulturae 2022, 8, 67. https://doi.org/10.3390/ horticulturae 8010067

Academic Editors: Rosario Paolo Mauro, Carlo Nicoletto, Leo Sabatino and Luigi De Bellis

Received: 30 November 2021

Accepted: 2 January 2022

Published: 11 January 2022

Publisher's Note: MDPI stays neutral with regard to jurisdictional claims in published maps and institutional affiliations.

Copyright: (C) 2022 by the authors. Licensee MDPI, Basel, Switzerland. This article is an open access article distributed under the terms and conditions of the Creative Commons Attribution (CC BY) license (https:// creativecommons.org/licenses/by/ $4.0 /)$
1 Department of Botany, Karnatak University, Dharwad 580003, Karnataka, India; shrinivasg192@gmail.com

2 Department of Microbiology and Fermentation Technology, CSIR-CFTRI, Mysuru 570020, Karnataka, India; anuapps@yahoo.com

3 Plant Production Department, College of Food \& Agriculture Sciences, King Saud University, Riyadh 11451, Saudi Arabia

4 Institute of Agricultural and Environmental Sciences, Estonian University of Life Sciences, Fr. R. Kreutzwaldi 1, 51006 Tartu, Estonia; jesamine@emu.ee

* Correspondence: hnmurthy60@gmail.com (H.N.M.); ydewir@ksu.edu.sa (Y.H.D.)

\begin{abstract}
Wood apple (Limonia acidissima L.) is an underutilized, fruit-yielding tree that is native to India and Sri Lanka. Wood apple trees are also cultivated in India, Sri Lanka, Bangladesh, Myanmar, Thailand, Malaysia, Vietnam, Kampuchea, Laos, and Indonesia for delicious fruits and medicinal purposes. The major objective of the present work was the analysis of the nutritional status of wood apple fruit pulp.The fruits are rich in total carbohydrates $(24.74 \pm 0.19 \%)$, total proteins $(9.30 \pm 0.16 \%)$, oil $(0.99 \pm 0.01 \%)$, fiber $(3.32 \pm 0.02 \%)$, and ash $(2.73 \pm 0.12 \%)$. Further analysis and quantification of free sugars, organic acids, and fatty acid methyl esters were carried out by using high-performance liquid chromatography (HPLC) and gas chromatographic (GC) methods. In total, five sugars and nine organic acids were detected and quantified. The predominant sugars were fructose $(16.40 \pm 0.23 \%)$ and glucose $(14.23 \pm 0.10 \%)$, whereas the predominant organic acids were $D$ tartaric $(4.01 \pm 0.03 \%)$, ascorbic $(4.51 \pm 0.05 \%)$, and citric acid $(4.27 \pm 0.04 \%)$. The oil content of fruit pulp was $0.99 \pm 0.01 \%$ and GC-MS analysis revealed that, it comprise of 16 fatty acid methyl esters. The percentage of saturated fatty acids were $32.17 \pm 0.35 \%$, that includes palmitic $(18.52 \pm 0.12 \%)$ and stearic acids $(9.02 \pm 0.08 \%)$, whereas, the unsaturated fatty acids were $51.98 \pm 0.94 \%$, including oleic acid (23.89 $\pm 0.06 \%), \alpha$-linolenic acid $(16.55 \pm 0.26 \%)$, linoleic acid $(10.02 \pm 0.43 \%)$, and vaccenic
\end{abstract} acid $(1.78 \pm 0.23 \%)$

Keywords: fatty acids; free sugars; GC-MS; HPLC; organic acids; UPLC; wood apple

\section{Introduction}

Underutilized fruits are considered as a vital source of essential amino acids, vitamins, mineral elements, and dietary fiber. In addition to these constituents, fruits are also rich in proteins, fats, carbohydrates, and reducing and non-reducing sugars [1-6]. Underutilized fruits are not only a primary source of food, but also have immense therapeutical potential due to the presence of bioactive compounds, including antioxidants such as unsaturated fats, organic acids, and sugars [1-4,7,8]. Nutraceutical compounds, which are essential for the human diet and major constituents for the storage of energy and the structural and functional composition of cells, were achieved from oils and fats [9]. Fatty acids are related to the prevention of coronary heart diseases, diabetes, cancer, and depression [10]. Fatty acids are also considered as the major components of cell membranes and have biological activities that act to influence cell and tissue metabolism, function, and responsiveness to hormones and other signals [11]. Free sugars and organic acids contribute to the taste of fruit pulp. Sugars are considered as common source of energy in living organisms and are the major constituents present in nature [12]. In recent years, polysaccharides have 
attracted much attention from researchers because they play a major role with respect to structural material, respiratory substrate, and synthesis of macromolecules and also in the mechanisms of plant tissue resistance to desiccation $[13,14]$. Aside from their traditional uses, free sugars are also used as a potential source to improve the quality of foods [15].

Organic acids in fruits are rapidly oxidized in the metabolism; hence, they do not have adverse effects on the body. Organic acids, including citric and ascorbic acids, lower the $\mathrm{pH}$ and inhibit/kill the growth of spoilage-causing organisms in food products; that is why they are commonly used as a preservative in many food processing industries [16]. One of the nutritionally and medicinally important, underutilized, fruit-yielding tree species is Limonia acidissima L., belongs to Rutaceae family and it is native to India and Sri Lanka. It is commonly called as wood apple, elephant apple, or monkey fruit. It is found throughout the plains of India, particularly in drylands up to an elevation of $450 \mathrm{~m}$, and is a deciduous, slow-growing, erect tree that reaches a height of up to approximately 12 to $15 \mathrm{~m}$ with a few upward-reaching branches bending outwards near the summit where they are subdivided into slender branchlets drooping at the tips. The spines are axillary, short, straight, and 2-3 cm long on some of the zigzag twigs. The leaves are deciduous, alternate, dark green, and 3-5 inches long with oil glands and a slight lemon scent when crushed. The flowers are normally bisexual, small, numerous, dull red or greenish yellow in color (Figure 1) [17]. It has also been widely introduced and naturalized in Myanmar, Thailand, Malaysia, Vietnam, Kampuchea, Laos, and Indonesia. Wood apple is a seasonal fruit; in India, the fruit matures in the month of October and is available until January. The maximum yield per plant varies from 40.50 to $70.00 \mathrm{~kg}$, as does that of Aegle marmelos [18].

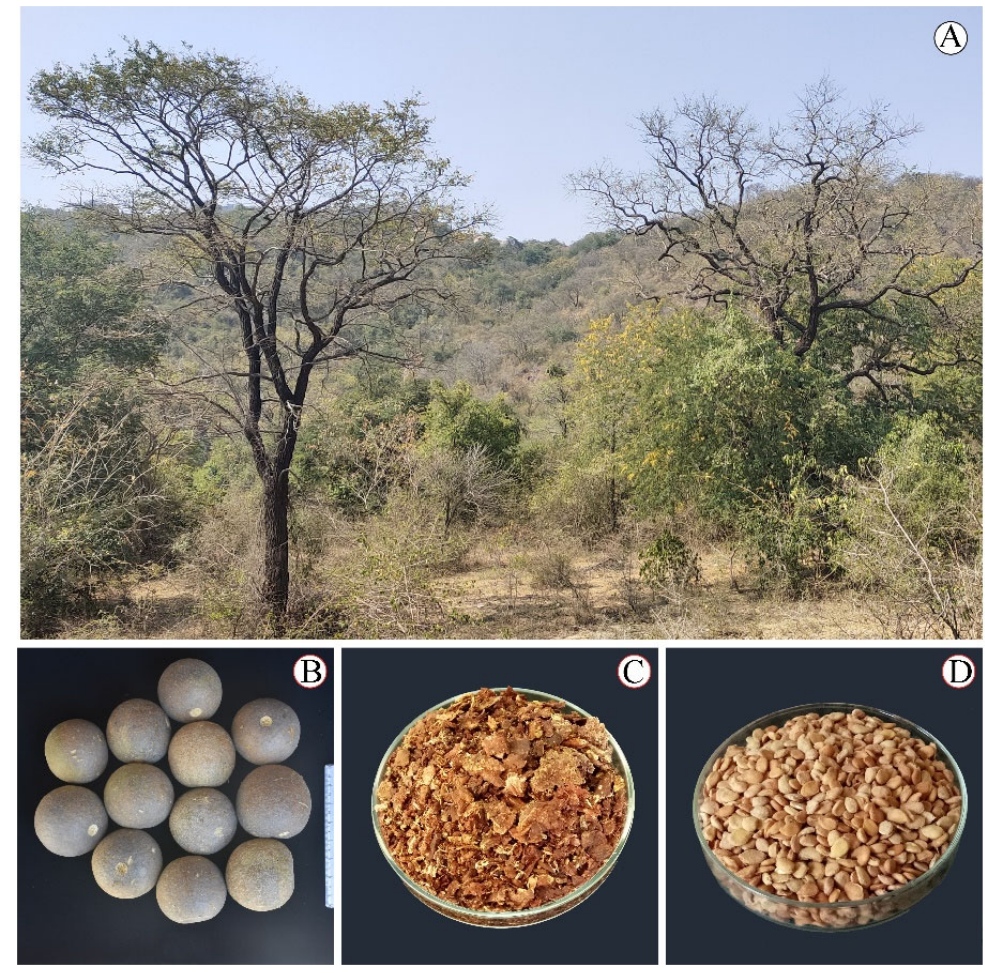

Figure 1. Wood apple (Limonia acidissima L.) - Tree habit (A), fruits (B), pulp (C), and seeds (D).

Wood apple is used by the tribal and rural population of the developing world, and also usage of such underutilized fruits facilitates an extra economic benefit to rural folk [2]. The pulp of the wood apple is eaten raw or blended with coconut milk and sugar syrup into juice. The pulp can be also be processed into a beverage or frozen like ice cream. The pulp is also made into chutney, preserves, jelly, marmalade, jam, jelly, and toffee [19]. Wood apple as a whole and its parts, such as leaves, roots, bark, and unripe and ripened fruits, have been used as medicine for the treatment of various ailments. Ethnopharmacological 
properties have been documented in various studies. The decoction of the leaves is used in the treatment of constipation and vomiting [20]. Bark and stem are used in treating liver diseases and hemorrhoids, respectively [21]. Fruits were used for the treatment of blood impurities, leucorrhoea, and as a diuretic [22]. Fruits are also used as a stomachic, stimulant, astringent, aphrodisiac, diuretic, cardiotonic, tonic to liver and lungs, a cure for coughs, hiccups, asthma, leucorrhoea, diarrhea, and also for wound healing activity [23]. Wood apple fruits are considered as a potential source of natural antioxidants and seed oil [24,25]. In earlier communication, we reported the fatty acid profile, and tocopherol content of the seed oil, and nutritional analysis of the seed cake of wood apple [25]. However, the composition of fatty acids, free sugars, and organic acids of wood apple fruit pulp is not yet reported. Therefore, the present work aimed to investigate the fatty acid composition in the pulp oil, free sugars, and organic acids, and the nutritional aspects of wood apple fruit pulp using advanced instruments such as GC-MS, UPLC-ELSD, and HPLC-PDA.

\section{Materials and Methods}

\subsection{Sample Collection and Separation}

Matured wood apple (Limonia acidissima L.) fruits were collected from Jogimatti reserve forest, Chitradurga District, Karnataka, India $\left(14^{\circ} 11^{\prime} 13.0^{\prime \prime} \mathrm{N}, 76^{\circ} 23^{\prime} 36.8^{\prime \prime} \mathrm{E}\right)$. Twenty matured plants were randomly selected from the site and 20 fruits were collected from each plant and pooled together for further study. A minimum distance of $20 \mathrm{~m}$ was maintained between the selected plants. Fruits were collected in their ripened stage, indicated by brown color during January. Pulp was collected from fresh fruits completely and stored at $-20{ }^{\circ} \mathrm{C}$ for future utilization. The separated pulp was dried by keeping in hot air oven (Serwell Instrument Incorporation, Bangalore, India) at $38 \pm 2{ }^{\circ} \mathrm{C}$ until it reached constant weight and was stored for future use.

\subsection{Chemicals and Standards}

$\mathrm{n}$-Hexane, methanol, potassium hydroxide, hydrochloric acid, 14\% methanolic boron trifluoride $(w / v)$, benzene, helium, diethyl ether, ethanol, acetonitrile, triethylamine, sulphuric acid, milli-Q water, acetone, phenolphthalein, chloroform, hanus iodine solution, potassium iodide, sodium thiosulfate, sodium hydroxide, PBS solution, bovine serum albumin, copper sulphate, folin-ciocalteu reagent, anthrone reagent, and sodium carbonate were of analytical grade from Merck, Bangalore (India). Fructose, glucose, sucrose, rhamnose, maltose, D-galacturonic acid, oxalic acid, D-tartaric acid, malic acid, ascorbic acid, acetic acid, citric acid, succinic acid, pyruvic acid, and gallic acid were purchased from Sigma-Aldrich, Bangalore, India.

\subsection{Extraction of Oil from Wood Apple Fruit Pulp}

Moisture-free pulp powder was used to extract oil with n-hexane using the coldpressed extraction method. The extract was concentrated using a rotary evaporator at $40^{\circ} \mathrm{C}$. The extracted oil was used for the analysis of fatty acid composition and the defatted fruit pulp was used for nutritional and nutraceutical analysis.

\subsection{Morphological and Proximate Characterization of Wood Apple Fruits}

The morphological characters of fruits were assayed from three different lots of fruits; each group consisted of 10 randomly collected matured fruits. Fruit length, width, and circumferance were measured using a Vernier caliper and the average weight of wood apple fruits was estimated gravimetrically. Separated wood apple fruit pulp was used to evaluate the proximate composition, including moisture, total ash, and crude fiber, and were determined according to the standard methods of AOAC [26]. Protein, carbohydrate, and crude fat contents were quantified by the method of Sadasivam and Manickam [27]. Titratable acidity, total soluble solids, and $\mathrm{pH}$ were assayed according to AOAC [28] methods. Briefly, $10 \mathrm{~g}$ of defatted fruit pulp was thoroughly mixed with $50 \mathrm{~mL}$ of milli-Q water at room temperature and used for analysis. Titratable acidity was determined as a 
percentage of citric acid. A total soluble solid was calculated directly using a refractometer (Erma handheld refractometer, Japan) and expressed in ${ }^{\circ}$ Brix. The $\mathrm{pH}$ was measured by homogenization of $1 \mathrm{mg}$ dried pulp sample in $10 \mathrm{~mL}$ of milli-Q water and then by immersing the electrode directly into a mixture of pulp using a $\mathrm{pH}$ meter (CD Instrumental Pvt. Ltd., Bangalore, India) [29]. The ash content in the sample was assessed according to the AOAC method [28].

\subsection{Extraction and Quantification of Total Phenolic Content}

The method of Singleton et al. [30] was used to assess the total phenolic content. Defatted pulp powder $(2 \mathrm{~g})$ was extracted with $20 \mathrm{~mL}$ of aqueous methanol $(80 \%, v / v)$. Aliquots of filtrate $(0.5 \mathrm{~mL})$ were taken into tubes and $3 \mathrm{~mL}$ of milli-Q water and $0.5 \mathrm{~mL}$ of Folin-Ciocalteu reagent (1:1) were added and homogenized thoroughly. After that, $2 \mathrm{~mL}$ of $20 \%(w / v)$ sodium carbonate was added and incubated for $30 \mathrm{~min}$ at room temperature in the dark. Absorbance was recorded at $760 \mathrm{~nm}$. The amount of phenolics was expressed as a percentage of gallic acid equivalent.

\subsection{Fatty Acid Composition}

Sample Preparation and Analysis of Fatty Acid Methyl Esters (FAMEs)

FAMEs were prepared according to Morison and Smith's method [31]. $1 \mathrm{~mL}$ of $0.7 \mathrm{~N}$ methanolic $\mathrm{KOH}(w / v)$ was used to saponify $10 \mathrm{mg}$ of oil and incubated for $1 \mathrm{~h}$ at $60^{\circ} \mathrm{C}$ in a water bath. It was cooled and $2 \mathrm{~mL}$ of hexane was added to discard the organic phase. The reaction was neutralized by adding $1 \mathrm{~mL}$ of $0.7 \mathrm{~N}$ methanolic HCL $(v / v)$ and $2 \mathrm{~mL}$ of hexane. The hexane pool was collected and evaporated to dryness under nitrogen air atmosphere. The evaporated tubes were methylated with $0.7 \mathrm{~mL}$ of $14 \%$ methanolic boron trifluoride and $0.3 \mathrm{~mL}$ of benzene. $2 \mathrm{~mL}$ of hexane was added and the FAMEs were collected and water washed. The hexane pool was collected again and evaporated and used for GC-MS analysis. Agilent 7890 B GC5977 A MSD GC-MS (Agilent Technologies, Santa Clara, CA, USA) system was used for the analysis of FAMEs. The separation was achieved with an Agilent CP8824 column (60 m length, $0.25 \mu \mathrm{m}$, i.d. $250 \mu \mathrm{m}$ ). The GC column temperature initially set at $80^{\circ} \mathrm{C}$ and held for $1 \mathrm{~min}$, then increased to $20^{\circ} \mathrm{C} / \mathrm{min}$ to $130{ }^{\circ} \mathrm{C}$, then $8.5^{\circ} \mathrm{C} / \mathrm{min}$ to $160^{\circ} \mathrm{C}$, then $2.75^{\circ} \mathrm{C} / \mathrm{min}$ to $200^{\circ} \mathrm{C}$ and held for $3 \mathrm{~min}$. Helium, with a flow rate of $1 \mathrm{~mL}$ per min, was used as a carrier gas. The injection volume was $1 \mu \mathrm{L}$ and the split ratio was 20:1. MS data were collected in an electron ionization mode at $70 \mathrm{eV}$ scanning from m/z 40 to 500 . Fatty acid methyl ester in each sample was identified with their mass spectrum data and results were confirmed by mass spectral library search (NIST $2.0 \mathrm{~g}$ ).

\subsection{Sugars and Organic Acids}

Sample Preparation Technique

Defatted fruit pulp (5 g) was extracted with $30 \mathrm{~mL}$ of aqueous methanol $(70 \%, v / v)$ in a round bottom flask at $40{ }^{\circ} \mathrm{C}$ with constant stirring. The same was repeated twice and the supernatant was collected and evaporated to dryness using a rotary evaporator (IKA-RV 10 digital rotary evaporator, IKA, Königswinter, Germany), and the concentrated sample was diluted to $10 \mathrm{~mL}$ with milli-Q water. For organic acid and sugar analysis, $10 \mu \mathrm{L}$ of samples were was injected into the HPLC system [16,32].

\subsubsection{LC Conditions for Sugars and Organic Acids}

\subsubsection{Investigation of Sugar Profile by UPLC-ELSD}

Sugar compositions of the sample were achieved with a ultra-high performance liquid chromatography system (Waters AQUITY UPLC H-Class) coupled with evaporative light scattering detector (ELSD) described by Koh et al. [33] with minor modifications. Separation was achieved with a UPLC ${ }^{\circledR}$ BEH amide column $(2.1 \times 100 \mathrm{~mm}$ i.d., $1.7 \mu \mathrm{m}$ particle size $)$, and the temperature was maintained at $35^{\circ} \mathrm{C}$. The condition of ELSD was: 200, gain; 40 psi, gas pressure; $40^{\circ} \mathrm{C}$, temperature of drift tube; cooling, nebulizer. Gradient elution program 
with acetonitrile: milli-Q water $(80 \%$ and $30 \%)$ used as eluents $\mathrm{A}$ and $\mathrm{B}$, respectively, with $0.2 \%$ triethylamine (TEA). The eluent flow rate was set at $0.12 \mathrm{~mL} / \mathrm{min}$ and the volume of injection was $2 \mu \mathrm{L}$. The gradient program followed as $60 \% \mathrm{~A}$ for $0-10 \mathrm{~min}, 60-100 \% \mathrm{~A}$ for 10-10.01 $\mathrm{min}$, and equilibrated at $18 \mathrm{~min}$. All samples were analyzed in triplicate and the analytes were identified by comparison (retention time and characteristic absorption) with authentic high purity standards (Sigma) and quantified through external standardization.

\subsubsection{Investigation of Organic Acids Profile by HPLC-PDA}

Organic acid profile was investigated with high-performance liquid chromatography (Shimadzu UFLC) equipped with SPD 20A detector and LC 20 AD system controller (photodiode array detector). The chromatographic separation was carried out with reversephase Phenomenex C18 column (Luna ${ }^{\circledR} 5 \mu \mathrm{m} \mathrm{C18} \mathrm{(2)} 100 \AA$, LC Column $250 \times 4.6 \mathrm{~mm}$ ) using an injection volume of $5 \mu \mathrm{L}$ and detected at $210 \mathrm{~nm}$. The mobile phase employed was $0.005 \mathrm{~N}$ sulphuric acid at a flow rate of $1 \mathrm{~mL}$ per minute in an isocratic mode of elution [34]. All samples were analyzed in triplicate and the analytes were identified by comparison (retention time and characteristic absorption) with authentic high purity standards (Sigma) and quantified through external standardization.

\subsubsection{Statistical Analysis}

All the determined values were estimated in triplicate $(n=3)$. Results are presented as mean \pm standard error (SE). Statistical analysis was carried out by using SPSS software.

\section{Results and Discussion}

\subsection{Morphological and Proximate Characterization of Wood Apple Fruits}

The collected wood apple fruits were round in shape and the average size of fruits, including length, width, and circumference, showed $7.42 \pm 0.19,7.43 \pm 0.10$, and $23.42 \pm 0.29 \mathrm{~cm}$, respectively, and the average weight of fruits was $179.45 \pm 1.42 \mathrm{~g}$ (Table 1). The studied morphological characters of wood apple fruits strongly agreed with the results of Singh et al. [35]. The nutritional estimation of fruit pulp is shown in Table 1 and it strongly agreed with the reports available [36,37]. Moisture content in the fruits is a considerably great parameter to assess the quality as it influences the texture, taste, shelf life, and growth of the microbes. Results showed $58.89 \pm 1.21 \%$ of moisture, which is comparatively less than Annona squamosa and Aegle mormelos (78.54\% and 64.71\%, respectively) [38,39]. Crude fat constitutes true fat and also the phospholipids, sterols, essential oils, and fat-soluble pigments. The crude fat value $(0.99 \pm 0.01 \%)$ strongly agreed with the reports of Cheema et al. [39] regarding Aegle mormelos (0.49\%) and Ziziphus nummularia (0.93\%).

The parameters which decide the quality, including total soluble solids, titratable acidity, and $\mathrm{pH}$, shown in the fruit pulp were $19.52 \pm 0.17{ }^{\circ}$ Brix, $4.61 \pm 0.13 \%$, and $3.61 \pm 0.09 \%$, respectively. To assess the internal quality of fruits, these parameters were considered as principal factors. The studied fruit pulp showed an approximately higher value of TSS compared to Annona squamosa, $23.10{ }^{\circ}$ Brix [38], and lower than Golden Delicious apple cultivar, $13.40 \%$ [40]. With respect to the titratable acidity, the studied fruit pulp showed $4.61 \pm 0.13 \%$ which is higher than Aegle mormelos, $1.2 \%$ [41]. The pH value reported in the fruit pulp was $3.61 \pm 0.09$, which is comparatively similar to the Golden Delicious apple cultivar, 3.79\% [40], and less than Phoenix dactylifera, 6.20, and sel-42 papaya cultivar, $4.03 \%[42,43]$.

Total ash content in the current study was $2.73 \pm 0.12 \%$ and it is comparable to the reported values of kumquat fruit [44]. The total ash content of the pulp was directly proportional to the presence of mineral elements. The crude fiber value obtained from the current study showed wood apple is a good source of dietary fiber, which is $3.32 \pm 0.02 \%$. Results revealed that the studied fruit pulp has a lower content of dietary fiber than kumquat fruit $(5.31 \%)$ [44]. It has been proposed that consumption of fruits with high dietary fiber has various health benefits including being a carrier of antioxidants in the gastrointestinal tract to reduce risk factors related to cardiovascular and intestinal diseases [45]. Total 
protein content was $25.24 \pm 0.07 \%$ and it is comparable with African mangosteen (31.76\%) and higher than kumquat fruits (7.38\%) [6,44]. A total of $24.74 \pm 0.19 \%$ of carbohydrate content was observed in the studied wood apple fruit pulp. Total carbohydrate content was comparatively higher than Annona squamosa (10.80\%) and kumquat fruits $(5.23 \%)[38,44]$. The total phenolics content was $0.50 \pm 0.01 \%$ and the phenolic values are comparable with Mauritian citrus fruits [46]. Nutritional analysis results reflect that wood apple fruit pulp is an important source to meet nutritional requirements because it plays a major role in human nutrition and health.

Table 1. Proximate and total phenolic composition of wood apple fruit pulp ${ }^{1}$.

\begin{tabular}{ccc}
\hline S1. No. & Parameters & Composition \\
\hline 1 & Fruit size (cm) & \\
& Length & $7.42 \pm 0.19$ \\
Width & $7.43 \pm 0.10$ \\
2 & Circumference & $23.42 \pm 0.29$ \\
3 & Fruit weight (g) & $179.45 \pm 1.42$ \\
4 & Moisture (\% FW) & $58.89 \pm 1.21$ \\
5 & Oil (\% FW) & $0.99 \pm 0.01$ \\
6 & TSS ( ${ }^{\circ}$ Brix) & $19.52 \pm 0.17$ \\
7 & pH & $3.61 \pm 0.09$ \\
8 & Titratable acidity (\% FW) & $4.61 \pm 0.13$ \\
9 & Ash (\% FW) & $2.73 \pm 0.12$ \\
10 & Crude fiber (\% FW) & $3.32 \pm 0.02$ \\
11 & Total protein (\% FW) & $9.30 \pm 0.16$ \\
12 & Total carbohydrate (\% FW) & $24.74 \pm 0.19$ \\
\hline
\end{tabular}

${ }^{1}$ Mean \pm standard error of triplicate determinations.. TSS-Total soluble solids; $\mathrm{pH}-$ Hydrogen ion concentration;

${ }^{2}$ Phenolic content was estimated as gallic acid equivalents.

\subsection{Fatty Acid Composition}

There are no previous reports on the wood apple fruit pulp fatty acid profile. The crude fat content in wood apple fruit pulp was $0.99 \pm 0.01 \%$ and the fatty acid profile represents the higher amount of unsaturated fatty acids. The fruits are rich in contents of unsaturated fatty acids are valuable sources for treating various ailments. Oils are essential for a healthy life because they are important natural sources of essential fatty acids [47,48]. Unsaturated fatty acids act as an important flavor precursor which plays a role in the storage and release of aroma components and directly influences aroma development [49].

The results showed (Table 2 and Figure 2) that the sum of saturated fatty acids (SFAs) was $32.17 \pm 0.35 \%$, whereas the monounsaturated fatty acids (MUFAs) were $26.20 \pm 0.33 \%$, and the polyunsaturated fatty acids (PUFAs) were $25.78 \pm 0.61 \%$ in the pulp oil of wood apple fruit. The abundance of unsaturated fatty acids was observed earlier in jujube fruits of 'Choutrana', 'Mahres', 'Mahdia', and 'Sfax' cultivars (68.5\% to 72.4\%) [50]. The most abundant PUFA detected in wood apple pulp oil was $\alpha$-linolenic acid (16.55 $\pm 0.26 \%$ ), followed by $10.02 \pm 0.43 \%$ of linoleic acid. The $\alpha$-linolenic acid and linoleic acid contents of the wood apple fruit pulp were higher than the observed results in the varieties of Ziziphus jujuba [48]. The results showed that wood apple pulp oil is a good source of essential fatty acids. Oleic acid $(23.89 \pm 0.06 \%)$ was the most predominant monounsaturated fatty acid observed and this is higher as compared to the observed results of genotypes of Ziziphus jujuba [47]. MUFAs are very well known for many health benefits and are a good source to decrease the success of low-density lipoprotein (LDL) cholesterol levels which bring down the heart-related risks [51]. 
Table 2. Fatty acid methyl ester compositions of wood apple (Limonia acidissima L.) fruit pulp oil ${ }^{1}$.

\begin{tabular}{|c|c|c|c|c|}
\hline Peak & $t_{R}(\min )$ & Common Name & Fatty Acid Methyl Esters & Value (\%) \\
\hline 1 & 7.93 & & Cyclooctasiloxane, hexadecamethyl- & $0.45 \pm 0.05$ \\
\hline 2 & 9.52 & & Cyclononasiloxane, octadecamethyl- & $0.38 \pm 0.05$ \\
\hline 3 & 9.66 & Acetophenone & Acetophenone & $2.34 \pm 0.06$ \\
\hline 4 & 9.95 & Lauric acid & Dodecanoic acid, methyl ester (C12:0) & $1.62 \pm 0.02$ \\
\hline 5 & 12.03 & Myristic acid & Methyl tetradecanoate (C14:0) & $1.74 \pm 0.04$ \\
\hline 6 & 13.21 & Pentadecylic acid & Pentadecanoic acid, methyl ester (C15:0) & $0.44 \pm 0.02$ \\
\hline 7 & 14.5 & Palmitic acid & Hexadecanoic acid, methyl ester (C16:0) & $18.52 \pm 0.12$ \\
\hline 8 & 15.09 & & Phenol, 2,4-bis(1,1-dimethylethyl)- & $7.70 \pm 0.06$ \\
\hline 9 & 17.42 & Stearic acid & Methyl stearate (C18:0) & $9.02 \pm 0.08$ \\
\hline 10 & 18.03 & Oleic acid & 9-Octadecenoic acid (Z)-, methyl ester (C18:1n9c) & $23.89 \pm 0.06$ \\
\hline 11 & 18.16 & Vaccenic acid & 11-Octadecenoic acid, methyl ester (C18:1n7) & $1.78 \pm 0.23$ \\
\hline 12 & 19.11 & Linoleic acid $(\omega-6)$ & 9,12-Octadecadienoic acid (Z,Z)-, methyl ester (C18:2n6) & $9.23 \pm 0.35$ \\
\hline 13 & 20.46 & $\alpha$-Linolenic acid $(\omega-3)$ & $\begin{array}{c}\text { 9,12,15-Octadecatrienoic acid, methyl ester, } \\
(\mathrm{Z}, \mathrm{Z}, \mathrm{Z})-(\mathrm{C} 18: 3 \mathrm{n} 3)\end{array}$ & $16.55 \pm 0.26$ \\
\hline 14 & 20.67 & Arachidic acid & Eicosanoic acid, methyl ester (C20:1) & $0.81 \pm 0.06$ \\
\hline 15 & 21.38 & Paullinic acid $(\omega-7)$ & cis-13-Eicosenoic acid, methyl ester (C20:1n7) & $0.52 \pm 0.03$ \\
\hline \multirow[t]{4}{*}{16} & 25.60 & & 2,5-di-tert-Butyl-1,4-dimethoxybenzene & $2.77 \pm 0.07$ \\
\hline & \multicolumn{3}{|c|}{$\sum$ Saturated fatty acids } & $32.17 \pm 0.35$ \\
\hline & \multicolumn{3}{|c|}{$\sum$ Monounsaturated fatty acids } & $26.20 \pm 0.33$ \\
\hline & \multicolumn{3}{|c|}{$\sum$ Polyunsaturated fatty acids } & $25.78 \pm 0.61$ \\
\hline
\end{tabular}

${ }^{1}$ Means \pm standard error of triplicate determinations.

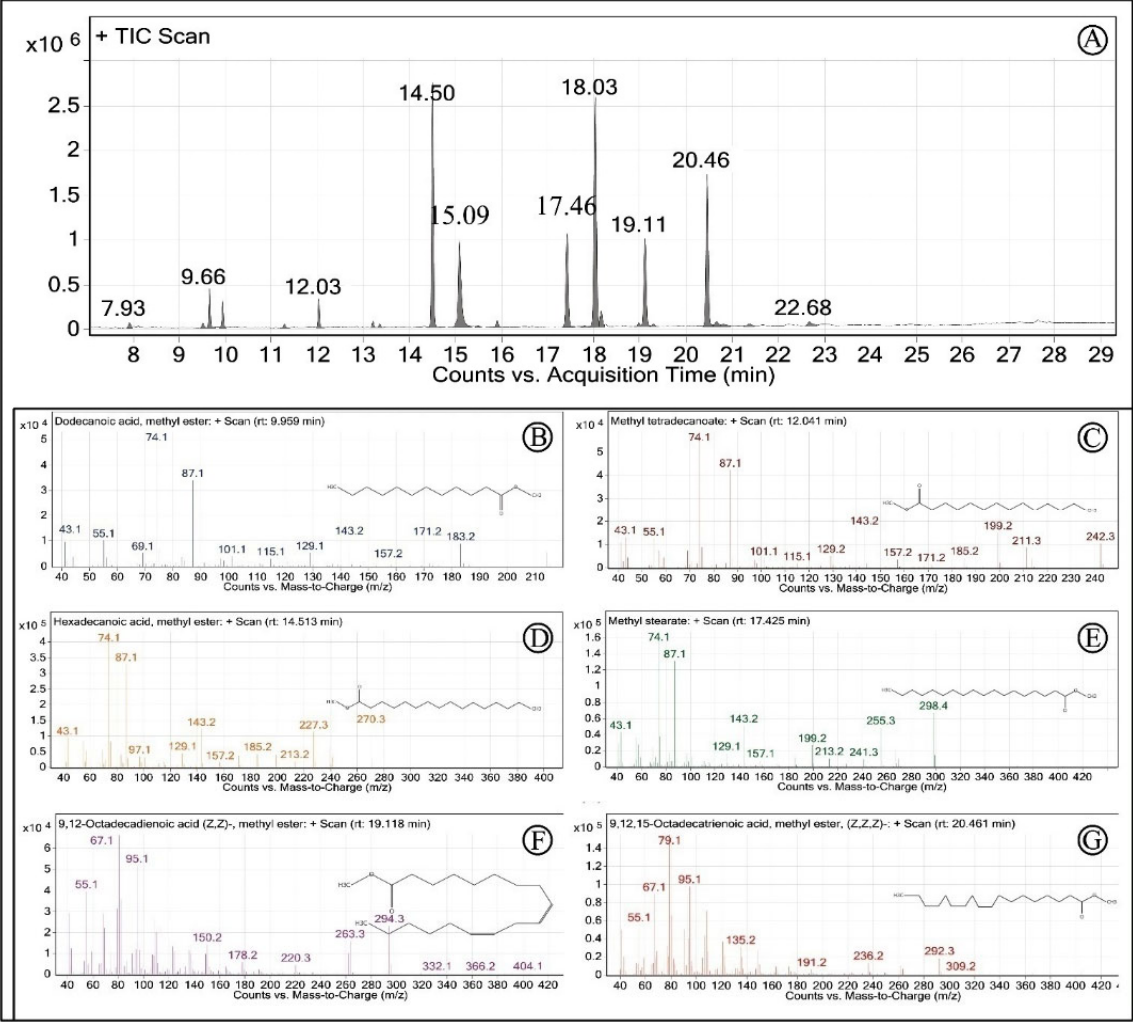

Figure 2. GC-MS chromatograms of wood apple (Limonia acidissima L.) fruit pulp oil fatty acid methyl esters (FAMEs) (A) and MS spectra of major FAMEs of analyzed fatty acids. Dodecanoic acid (B), methyl tetradecanoate (C), methyl palmitate (D), methyl stearate (E), methyl linoleate (F), methyl linolenate $(\mathbf{G})$.

The monounsaturated, fatty acid-rich oil is advisable in terms of nutrition and provides enough stability to be used for baking purposes [52]. The most abundant saturated fatty acid present in oil was palmitic acid (18.52 $\pm 0.12 \%)$, whereas the stearic acid, myristic 
acid, lauric acid, arachidic acid, and pentadecylic acids were $9.02 \pm 0.08 \%, 1.74 \pm 0.04 \%$, $1.62 \pm 0.02 \%, 0.81 \pm 0.06 \%$, and $0.44 \pm 0.02 \%$, respectively. Saturated fatty acids observed in wood apple fruit pulp were higher than the genotypes of Ziziphus jujuba [47]. A higher content of saturated fatty acids in oils represents that they have more oxidative stability, as well as that they are well accepted for cooking, including frying and baking, and are considered as important constituents for cell membranes, secretary, and transport lipids with crucial roles in protein palmitoylation and palmitoylated signal molecules [11,53]. Wood apple pulp oil showed a higher percentage of PUFAs, which have the important natural sources of essential fatty acids, omega- 3 and omega- 6 , and fruits with good fatty acid profiles have great health potential for both fresh consumption and/or industrial processing.

\subsection{Investigation of Sugar Profile by UPLC-ELSD}

The profiling of free sugars was achieved with the UPLC-ELSD and the results are shown in Figure 3 and Table 3. Sugars are much needed to decide the quality and maturity characters of fruits, whereas fructose and glucose are the vital components [54]. The total free sugar content in defatted fruit pulp was $31.59 \pm 0.17 \%$ DW, whereas the abundant sugars present in wood apple fruit pulp were fructose $(16.40 \pm 0.23 \%)$ and glucose $(14.23 \pm 0.10 \%)$, and the minor contents of sugars were rhamnose $(0.24 \pm 0.01 \%)$, sucrose $(0.13 \pm 0.01 \%)$, and maltose $(0.57 \pm 0.03 \%)$. During the period of total fruit maturation, the sugar content is increased and, at the time when the matured fruit detaches from the tree, it reaches the maximum level and the increased sugar content in wood apple is because of starch decomposition [55]. The fructose and glucose abundance in repined fruits makes the pulp soft and sweeter, which influence the quality of consumer acceptance [54], whereas the unripe fruits are very sour and astringent [56],

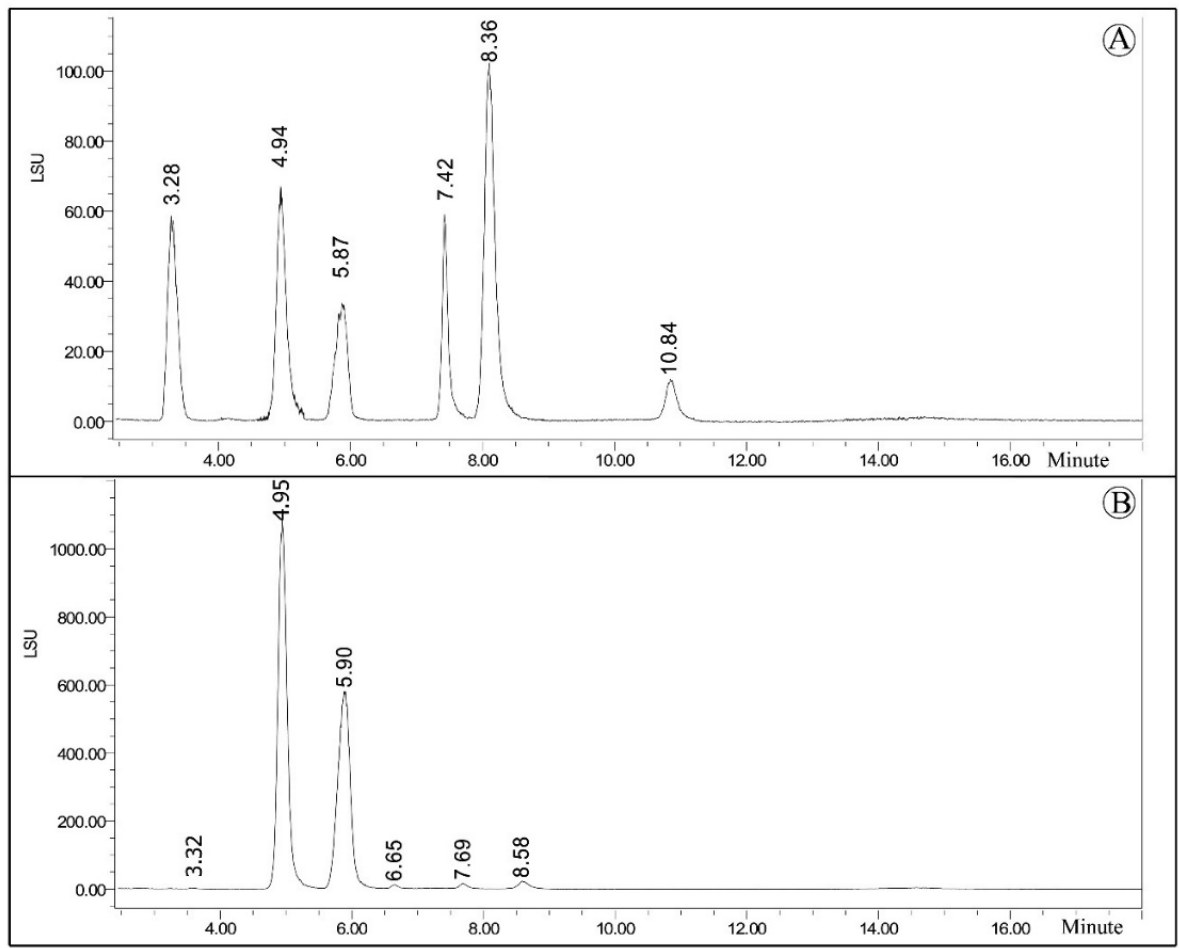

Figure 3. UPLC-ELSD chromatograms of free sugar standards (A) and wood apple (Limonia acidissima L.) fruit pulp (B). 
Table 3. Free sugar composition (\%) of wood apple defatted fruit pulp ${ }^{1}$.

\begin{tabular}{cccc}
\hline S1. No. & Retention Time & Free Sugars & Composition $^{2}$ \\
\hline 1 & 3.32 & Rhamnose & $0.24 \pm 0.01$ \\
2 & 4.93 & Fructose & $16.40 \pm 0.23$ \\
3 & 5.89 & Glucose & $14.23 \pm 0.10$ \\
4 & 7.71 & Sucrose & $0.13 \pm 0.01$ \\
5 & 8.33 & Maltose & $0.57 \pm 0.03$ \\
& Total sugars & & $31.59 \pm 0.17$ \\
\hline
\end{tabular}

${ }^{1}$ DW—Dry weight. ${ }^{2}$ Means \pm standard error of triplicate determinations.

\subsection{Investigation of Organic Acid Profile by HPLC-PDA}

The present study showed nine organic acids, including galacturonic acid, oxalic acid, tartaric acid, malic acid, ascorbic acid, acetic acid, citric acid, succinic, and pyruvic acid. Fruit flavor may be contributed to by the presence of different types of organic acids in fruits. The results of the organic acid analysis is shown in Table 4 and Figure 4 . The total amount of organic acid present in wood apple pulp was $17.46 \pm 0.23 \%$ DW. The major organic acids were ascorbic acid $(4.51 \pm 0.05 \%)$, citric acid $(4.27 \pm 0.04 \%)$, and tartaric acid $(4.01 \pm 0.03 \%)$, whereas, the amount of succinic acid $(1.83 \pm 0.03 \%)$, galacturonic acid $(0.93 \pm 0.02 \%)$, acetic acid $(0.81 \pm 0.06 \%)$, pyruvic acid $(0.79 \pm 023 \%)$, malic acid $(0.23 \pm 0.01 \%)$, and oxalic acid $(0.05 \pm 0.01 \%)$ were in minor concentrations. The citric acid content in passion fruit (4.35\%) was approximately equal, whereas in Ficus carica it was $0.69 \%$ and Ziziphus jujuba 0.19\% [57,58]. Malic and succinic acids in Ziziphus jujuba were $0.22 \%$ and $0.01 \%$ respectively [57]. Many studies revealed that the fruit's of citrus family is majorly constituted of citric acid, malic acid, quininic acid, and oxalic acid. Together, these organic acids influence the citrus fruit acidity. Among these organic acids, citric acid is the largest contributor to the acidity taste and accounted for $79 \%, 71 \%$, and $45 \%$ of total organic acids in acidic lemon, lime, and orange, respectively [59].

Table 4. Organic acid compositions of wood apple defatted fruit pulp (\% DW) ${ }^{1}$.

\begin{tabular}{cccc}
\hline S1. No. & $\mathbf{t}_{\mathbf{R}}(\mathbf{m i n})$ & Organic Acids & Composition $^{\mathbf{2}}$ \\
\hline 1 & 3.06 & D-Galacturonic acid & $0.93 \pm 0.02$ \\
2 & 3.37 & Oxalic acid & $0.05 \pm 0.01$ \\
3 & 3.55 & D-Tartaric acid & $4.01 \pm 0.03$ \\
4 & 4.48 & Malic acid & $0.23 \pm 0.01$ \\
5 & 4.74 & Ascorbic acid & $4.51 \pm 0.05$ \\
6 & 5.59 & Acetic acid & $0.81 \pm 0.06$ \\
7 & 8.74 & Citric acid & $4.27 \pm 0.04$ \\
8 & 9.59 & Succinic acid & $1.83 \pm 0.03$ \\
9 & 13.31 & Pyruvic acid & $0.79 \pm 0.01$ \\
& Total organic acids & & $17.46 \pm 0.23$ \\
\hline
\end{tabular}

${ }^{1}$ DW-Dry weight. ${ }^{2}$ Means \pm standard error of triplicate determinations. 


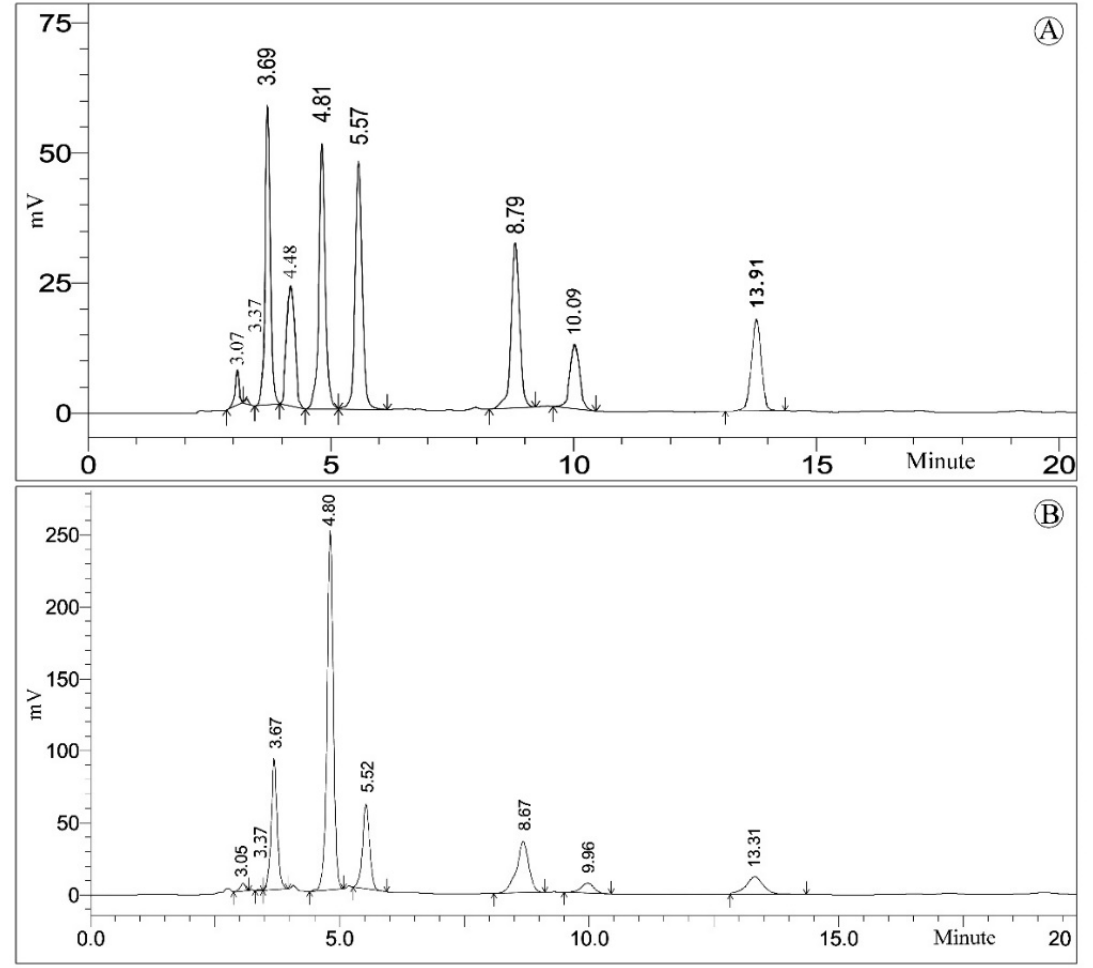

Figure 4. HPLC-PDA chromatograms of organic acid standards (A) and wood apple (Limonia acidissima L.) fruit pulp (B).

\section{Conclusions}

The characterization of wood apple fruit pulp showed a higher percentage of carbohydrate $(24.74 \pm 0.19 \%)$, protein $(9.30 \pm 0.16 \%)$, ash $(2.73 \pm 0.12 \%)$, and fiber $(3.32 \pm 0.02 \%)$, which is comparable to other citrus fruits such as bael (Aegle mermelos) and kumquat (Fortunella marginata). Wood apple fruits are also rich in organic acids, such as D-tartaric, ascorbic, and citric acid, which are accountable for the taste and quality of the fruits. The total free sugar content in defatted wood apple fruit pulp was $31.59 \pm 0.17 \%$ DW. Fructose $(16.40 \pm 0.23 \%)$ and glucose $(14.23 \pm 0.10 \%)$ were the major sugars of the fruit pulp. Fatty acid profiling revealed that wood apple possesses a higher percentage of unsaturated fatty acids including oleic, $\alpha$-linolenic, linoleic, and vaccenic acids. The results of the present study showed that the wood apple fruits are rich in nutritional components.

Author Contributions: Conceptualization, H.N.M. and K.A.A.-A.; methodology, H.N.M., K.A.A.-A., and Y.H.D.; Formal analysis, H.N.M., K.A.A.-A., Y.H.D., and J.J.R.; investigation and data curation, S.L. and H.N.M.; validation, S.L., H.N.M., K.A.A.-A., Y.H.D., and J.J.R.; writing-original draft preparation, S.L., H.N.M., K.A.A.-A., and Y.H.D.; writing-review and editing, S.L., H.N.M., K.A.A.-A., Y.H.D., and J.J.R. All authors have read and agreed to the published version of the manuscript.

Funding: Researchers Supporting Project number (RSP-2021/375), King Saud University, Riyadh, Saudi Arabia.

Institutional Review Board Statement: Not applicable.

Informed Consent Statement: Not applicable.

Data Availability Statement: All data are presented within the article.

Acknowledgments: The authors acknowledge Researchers Supporting Project number (RSP-2021/375), King Saud University, Riyadh, Saudi Arabia.

Conflicts of Interest: The authors declare no conflict of interest. 


\section{References}

1. Murthy, H.N.; Bapat, V.A. Importance of underutilized fruits and nuts. In Bioactive Compounds in Underutilized Fruits and Nuts, Reference Series in Phytochemistry; Murthy, H.N., Bapat, V.A., Eds.; Springer Nature: Cham, Switzerland, 2020; pp. 3-19.

2. Murthy, H.N.; Dalawai, D. Bioactive compounds of wood apple (Limonia acidissima L.). In Bioactive Compounds in Underutilized Fruits and Nuts, Reference Series in Phytochemistry; Murthy, H.N., Bapat, V.A., Eds.; Springer Nature: Cham, Switzerland, 2020; pp. 543-569.

3. Murthy, H.N.; Dalawai, D.; Dewir, Y.H.; Ibrahim, A. Phytochemicals and biological activities of Garcinia morella (Gaertn.) Desr.: A review. Molecules 2020, 25, 5690. [CrossRef]

4. Murthy, H.N.; Yadav, G.G.; Dewir, Y.H.; Ibrahim, A. Phytochemicals and biological activity of desert date (Belanites aegyptica (L.) Delile). Plants 2020, 10, 32. [CrossRef]

5. Manohar, S.H.; Naik, P.M.; Patil, L.M.; Karikatti, S.I.; Murthy, H.N. Chemical composition of Garcinia xanthochymus seeds, seed oil, and evaluation of its antimicrobial and antioxidant activity. J. Herbs Spices Med. Plants 2014, 20, 148-155. [CrossRef]

6. Joseph, K.S.; Bolla, S.; Joshi, K.; Bhat, M.; Naik, K.; Patil, S.; Bendre, S.; Gangappa, B.; Haibatti, V.; Payamalle, S.; et al. Determination of chemical composition and nutritive value with fatty acid compositions of African Mangosteen (Garcinia livingstonei). Erwerbs-Obstbau 2016, 59, 195-202. [CrossRef]

7. Murthy, H.N.; Dalawai, D.; Mamatha, U.; Angadi, N.B.; Dewir, Y.H.; Al-Suhaibani, N.A.; El-Hendawy, S.; Al-Ali, A.M. Bioactive constituents and nutritional composition of Bridelia stipularis L. Blume fruits. Int. J. Food Prop. 2021, 24, 796-805. [CrossRef]

8. Murthy, H.N.; Dandin, V.S.; Dalawai, D.; Park, S.Y.; Paek, K.Y. Bioactive compounds from Garcinia fruits of high economic value for food and health. In Bioactive Molecules in Food, Reference Series in Phytochemistry; Merllion, J.M., Ramawat, K.G., Eds.; Springer Nature: Cham, Switzerland, 2018; pp. 1-26.

9. Yoshida, H.; Hirakawa, Y.; Abe, S. Roasting influences on molecular species of triacylglycerols in sunflower seeds (Helianthus annuus L.). Food Res. Int. 2001, 34, 613-619. [CrossRef]

10. Timilsena, Y.P.; Vongsvivut, J.; Adhikari, R.; Adhikari, B. Physicochemical and thermal characteristics of Australian chia seed oil. Food Chem. 2017, 228, 394-402. [CrossRef]

11. German, J.B. Dietary lipids from an evolutionary perspective: Sources, structures and functions. Matern. Child Nutr. 2011, 7, 2-16. [CrossRef]

12. Westman, E.C. Is dietary carbohydrate essential for human nutrition? Am. J. Clin. Nutr. 2002, 75, 951-953. [CrossRef]

13. Yu, S.M. Cellular and genetic responses of plants to sugar starvation. Plant Physiol. 1999, 121, 687-693. [CrossRef] [PubMed]

14. Finkle, B.J.; Zavala, M.E.; Ulrich, J.M. Cryoprotective compounds in the viable freezing of plant tissues. In Cryopreservation of Plant Cells and Organs; Kartha, K.K., Ed.; CRC Press Inc.: Boca Raton, FL, USA, 1985; pp. 75-115.

15. Bekers, M.; Marauska, M.; Grube, M.; Karklina, D.; Duma, M. New prebiotics for functional food. Acta Aliment. 2004, 33 , 31-37. [CrossRef]

16. Rai, A.K.; Prakash, M.; Anu Appaiah, K.A. Production of Garcinia wine: Changes in biochemical parameters, organic acids and free sugars during fermentation of Garcinia must. Int. J. Food Sci. Technol. 2010, 45, 1330-1336. [CrossRef]

17. Orwa, C.; Mutua, A.; Kindt, R.; Jamnadass, R.; Anthony, S. Agroforestry Database: A Tree Reference and Selection Guide Version 4.0; World Agroforestry Centre: Nairobi, Kenya, 2009.

18. Singh, A.K.; Singh, S.; Singh, R.S.; Joshi, H.K.; Sharma, S.K. Characterization of bael (Aegle marmelos) varieties under rainfed hot semi-arid environment of western India. Indian J. Agric. Sci. 2014, 84, 1236-1242.

19. Lim, T.K. Limonia acidissima . In Edible Medicinal and Non-Medicinal Plants: Fruits; Lim, T.K., Ed.; Springer Science \& Business Media: Berlin/Heidelberg, Germany, 2012; Volume 4, pp. 884-889.

20. Chatterjee, T.K. Herbal Options, 3rd ed.; Books and Allied (P) Ltd.: Calcutta, India, 2003; pp. $203-256$.

21. Joshi, R.K.; Badakar, V.M.; Kholkute, S.D.; Khatib, N. Chemical composition and antimicrobial activity of the essential oil of the leaves of Feronia elephantum (Rutaceae) from North West Karnataka. Nat. Prod. Commun. 2011, 6, 141-143. [CrossRef] [PubMed]

22. Gupta, R.; Johri, S.; Saxena, A.M. Effect of ethanolic extract of Feronia elephantum Correa fruits on blood glucose levels in normal and streptozotocin induced diabetic rats. NPR 2009, 8, 32-36.

23. Ilango, K.; Chitra, V. Wound healing and antioxidant activities of the fruit pulp of Limonia acidissima Linn (Rutaceae) in rats. Trop. J. Pharm. Res. 2010, 9, 223-230. [CrossRef]

24. Ilaiyaraja, N.; Likhith, K.R.; Sharath Babu, G.R.; Khanum, F. Optimization of extraction of bioactive compounds from Feronia limonia (wood apple) fruit using response surface methodology (RSM). Food Chem. 2015, 173, 348-354. [CrossRef] [PubMed]

25. Lamani, S.; Anu-Appaiah, K.A.; Murthy, H.N.; Dewir, Y.H.; Rihan, H.Z. Fatty acid profile, tocopherol content of seed oil, and nutritional analysis of seed cake of wood-apple (Limonia acidissima L.), an underutilized fruit-yielding tree species. Horticulturae 2021, 7, 275. [CrossRef]

26. AOAC. Official Methods of Analysis of AOAC International; AOAC: Gaithersburg, MD, USA, 2005.

27. Sadasivam, S.; Manickam, A. Biochemical Methods, 3rd ed.; New Age International (P) Limited, Publishers: New Delhi, India, 2008.

28. AOAC. Official Methods of Analysis of Association of Analytical Chemists, 15th ed.; AOAC: Washington, DC, USA, 1998.

29. Anonymous. Manual of Methods of Analysis of Foods: Fruit and Vegetable Products. Lab. Manual 5; Food Safety and Standards Authority of India; Ministry of Health and Family Welfare: New Delhi, India, 2015; Volume 40, p. 11. 
30. Singleton, V.L.; Orthofer, R.; Lamuela-Raventos, R.S. Analysis of total phenols and other oxidation substrates and antioxidants by means of Folin-ciocalteau Reagent. Methods Enzymol. 1999, 299, 152-178.

31. Morison, W.R.; Smith, L.M. Preparation of fatty acid methyl esters and dimethylacetals from lipids with boron fluoride-methanol. J. Lipid Res. 1964, 5, 600-608. [CrossRef]

32. Ghfar, A.A.; Wabaidur, S.M.; Ahmed, A.Y.B.H.; Alothman, Z.A.; Khan, M.R.; Al-Shaalan, N.H. Simultaneous determination of monosaccharides and oligosaccharides in dates using liquid chromatography-Electrospray ionization mass spectrometry. Food Chem. 2015, 176, 487-492. [CrossRef] [PubMed]

33. Koh, D.; Park, J.; Lim, J.; Yea, M.; Bang, D. A rapid method for simultaneous quantification of 13 sugars and sugar alcohols in food products by UPLC-ELSD. Food Chem. 2018, 240, 694-700. [CrossRef] [PubMed]

34. Jayaprakasha, G.K.; Sakariah, K.K. Determination of organic acids in Garcinia cambogia (Desr.) by high-performance liquid chromatography. J. Chromatogr. A 1998, 806, 337-339. [CrossRef]

35. Singh, A.K.; Singh, S.; Yadav, V.; Sharma, B.D. Genetic variability in wood apple (Feronia limonia) from Gujarat. Indian J. Agric. Sci. 2016, 86, 1504-1508.

36. Poongodi Vijayakumar, T.; Punitha, K.; Banupriya, L. Drying characteristics and quality evaluation of wood apple (Limonia acidissima L.) fruit pulp powder. Int. J. Curr. Trends Res. 2013, 2, 147-150.

37. Sonawane, S.K.; Bagul, M.B.; LeBlanc, J.G.; Arya, S.S. Nutritional, functional, thermal and structural characteristics of Citrullus lanatus and Limonia acidissima seed flours. J. Food Meas. Charact. 2016, 10, 72-79. [CrossRef]

38. Abdualrahman, M.A.Y.; Ma, H.; Zhou, C.; Yagoub, A.E.A.; Ali, A.O.; Tahir, H.E.; Wali, A. Postharvest physicochemical properties of the pulp and seed oil from Annona squamosa L. (Gishta) fruit grown in Darfur region, Sudan. Arab. J. Chem. 2019, 12, 4514-4521. [CrossRef]

39. Cheema, J.; Yadav, K.; Sharma, N.; Saini, I.; Aggarwal, A. Nutritional quality characteristics of different wild and underutilized fruits of Terai region, Uttarakhand (India). Int. J. Fruit Sci. 2016, 17, 72-81. [CrossRef]

40. Wu, J.; Gao, H.; Zhao, L.; Liao, X.; Chen, F.; Wang, Z.; Hu, X. Chemical compositional characterization of some apple cultivars Food Chem. 2007, 103, 88-93. [CrossRef]

41. Sagar, V.R.; Kumar, R. Effect of drying treatments and storage stability on quality characteristics of bael powder. J. Food Sci. Technol. 2014, 51, 2162-2168. [CrossRef] [PubMed]

42. Siddeeg, A.; Zeng, X.; Ammar, A.; Han, Z. Sugar profile, volatile compounds, composition and antioxidant activity of sukkari date palm fruit. J. Food Sci. Technol. 2019, 56, 754-762. [CrossRef]

43. Kelebek, H.; Selli, S.; Gubbuk, H.; Gunes, E. Comparative evaluation of volatiles, phenolics, sugars, organic acids and antioxidant properties of Sel-42 and Tainung papaya varieties. Food Chem. 2015, 173, 912-919. [CrossRef] [PubMed]

44. e Souza, C.S.; Anunciacao, P.C.; Della Lucia, C.M.; Rodrigues das Dores, R.G.; de Miranda Milagres, R.C.R.; Pinheiro Sant'Ana, H.M. Kumquat (Fortunella marginata): A good alternative for ingestion of nutrients and bioactive compounds. Proceedings 2021, 70, 105. [CrossRef]

45. Saura-Calixto, F. Dietary fiber as a carrier of dietary antioxidants: An essential physiological function. J. Agric. Food. Chem. 2011, 59, 43-49. [CrossRef]

46. Ramful, D.; Bahorun, T.; Bourdon, E.; Tarnus, E.; Aruoma, O.I. Biactive phenolics and antioxidant propensity of flavedo extracts of Mauritian citrus fruits: Potential prophylactic ingredients for functional food application. Toxicology 2010, 278, 75-87. [CrossRef]

47. San, B.; Yildirim, A.N. Phenolic, alpha-tocopherol, beta-carotene and fatty acid composition of four promising jujube (Ziziphus jujuba Miller) selections. J. Food Compos. Anal. 2010, 23, 706-710. [CrossRef]

48. Reche, J.; Almansa, M.S.; Hernandez, F.; Carbonell-Barrachina, A.A.; Legua, P.; Amoros, A. Fatty acid profile of peel and pulp of Spanish jujube (Ziziphus jujuba Mill.) fruit. Food Chem. 2019, 295, 247-253. [CrossRef]

49. Sanchez-Salcedo, E.M.; Sendra, E.; Carbonell-Barrachina, A.A.; Martínez, J.J.; Hernandez, F. Fatty acids composition of Spanish black (Morus nigra L.) and white (Morus alba L.) mulberries. Food Chem. 2016, 190, 566-571. [CrossRef]

50. Elaloui, M.; Laamouri, A.; Albouchi, A.; Cerny, M.; Mathieu, C.; Vilarem, G.; Hasnaoui, B. Chemical compositions of the tunisian Ziziphus jujuba oil. Emir. J. Food Agric. 2014, 26, 602-608. [CrossRef]

51. FAO/WHO. Fats and fatty acids in human nutrition. In Report of an Expert Consultation; FAO/WHO: Geneva, Switzerland, 2010.

52. Petukhov, I.; Malcolmson, L.J.; Przybylski, R.; Armstrong, L. Frying performance of genetically modified canola oils. JAOCS 1999, 76, 627-632. [CrossRef]

53. Matthaus, B. Use of palm oil for frying in comparison with other high-stability oils. Eur. J. Lipid Sci. Technol. 2007, 109, 400-409. [CrossRef]

54. Hu, W.; Sun, D.W.; Pu, H.; Pan, T. Recent developments in methods and techniques for rapid monitoring of sugar metabolism in fruits. Compr. Rev. Food Sci. Food Saf. 2016, 15, 1067-1079. [CrossRef]

55. Murrinie, E.D.; Yudono, P.; Purwantoro, A.; Sulistyaningsih, E. Morphological and physiological changes during growth and development of wood apple (Feronia limonia (L.) Swingle) fruit. Int. J. Bot. 2017, 13, 75-81. [CrossRef]

56. Seymour, G.B.; Taylor, J.E.; Tucker, C.A. Biochemistry of Fruit Ripening; Chapman and Hall: London, UK, 1993.

57. Gao, Q.H.; Wu, C.S.; Wang, M.; Xu, B.N.; Du, L.J. Effect of drying of jujubes (Ziziphus jujuba Mill.) on the contents of sugars, organic acids, $\alpha$-tocopherol, $\beta$-carotene, and phenolic compounds. J. Agric. Food Chem. 2012, 60, 9642-9648. [CrossRef] [PubMed] 
58. Slatnar, A.; Klancar, U.; Stampar, F.; Veberic, R. Effect of Drying of Figs (Ficus carica L.) on the contents of sugars, organic acids and phenolic compounds. J. Agric. Food Chem. 2011, 59, 11696-11702. [CrossRef] [PubMed]

59. Albertini, M.; Carcouet, E.; Pailly, C.O.; Gambotti, C.; Luro, F.; Berti, L. Changes in organic acids and sugars during early stages of development of acidic and acidless citrus fruit. J. Agric. Food Chem. 2006, 54, 8335-8339. [CrossRef] 